\title{
PARADIGM OF HISTORICAL SCIENCE: DEALING WITH THE MODERN JUGGERNAUT THROUGH ACROSS TIME IN EDUCATION AND GOVERNMENT
}

\author{
Safin Karunia Rojuli, Moses Glorino Rumambo Pandin \\ Faculty of Humanities, Universitas Airlangga \\ safin.karunia.rojuli-2020@,fib.unair.ac.id, moses.glorino@,fib.unair.ac.id
}

\begin{abstract}
In this modern era, continuous change is the first step in forming a new structure between theory and practice. The idea of a juggernaut is very relevant to the theory of structuration with current conditions in the 21 st century, where technology becomes a reference that can crush anyone who is not responsive to its power. This technology takes one path and takes many roles from various fields: economic, social, political, legal, and educational. This $21 \mathrm{st}$ century is marked by great momentum for changes in human behavior and civilization, namely the industrial revolution 4.0 and the arrival of Covid-19, which have changed many social structures and human activities. This makes history a means of connecting the problems in the 21 st century with past events. By using a descriptive qualitative method, this paper will reveal how technological developments are very influential on educational and political developments and what are the challenges faced based on historical perspective?. In this case, the study aims to discuss the history and challenges of Indonesia's education system and government system in the 21 st century and give a solution. The data used are from 2 books, 14 journal articles, and 4 websites with a span of 2019-2021. The research results are expected to be used as a further study in the face of the development of the modern era in the fields of education and government. This study also has limitations, namely only on the face of the development of the modern era in the fields of education and government.
\end{abstract}

Keywords: 21 st century, Covid 19, education, the government system 


\section{INTRODUCTION}

Entering the changing times is constantly the first step in forming a new structure between theory and practice. The same thing happens in the process of changing the structure that humans perceive. From one revolution to the next, the structure of reality has changed, leading human civilization always to enter the latest phase. Along with the development of the times, technology is also increasingly sophisticated in helping people's daily lives (Lukman Hakim, 2020: 59)(1). If the technology is used correctly, it will produce positive things and vice versa. If it is used excessively and not in an inappropriate manner, it will turn the technology into a negative thing. This technology also plays a role in all fields, including politics and education.

Juggernaut is described as a large machine that can crush anyone who is not responsive to its power. The democratic system gives the movement juggernauts freedom, through the development of science and technology, humans are still in modernity. Now democracy makes room for modernity and a giant object called the emerged juggernaut of modernity. Democracy has opened up the dialectical space as a whole, both of them argue that the government is the enemy and those who state that the government is considered right to implement true democracy (Lukman Hakim, 2020: 113). (1)

Why is this worth discussing? Changes in the Indonesian government system affect changing the form of democracy. In the history of Indonesia, there were 4 periods of democracy with a different system. First, during the liberal democratic government system at the beginning of Indonesia's independence. During President Soekarno's reign, the two systems of guided democracy had been implied by the government at that time, Then President Soekarno also dissolved the constituent assembly. Third, the Pancasila democratic system was applied during President Suharto's reign, who led for quite a long time. Fourth, the current democratic system is still considered to be in a transitional period (2). The development of democracy that is carried out is still based on representation. (Wijaya, et al., 2019). Changes in the democratic system in Indonesia from President Soekarno's leadership have not been able to fully improve the Indonesian government system. (3)

Apart from the government, Human Resources (HR) quality also supports progress in a country including Indonesia. If human resources in Indonesia are compared to 3 countries in Asia, Indonesia is still below Singapore with a score of 0.88 and Vietnam with a score of 0.67 (reported from Kompas.com, 2019)(4). Improving the quality of education is a renewal process in improving the quality of Human Resources. Improving education is 
supported by facilities and infrastructure and is accompanied by the willingness of every human resource to be better.

From this explanation, changes are needed to the education system in Indonesia in developing the curriculum and the development of the government system that is run in Indonesia. Therefore, this article aims to provide solutions for implementing government and education systems to deal with modern juggernauts. To realize an education system that can improve human resources, there are four pillars offered by UNESCO, 1) Learning to know, 2) Learning to do, 3) Learning to live together, 4) Learning to be(5). Indonesia has a promising prospect for democracy. The condition for achieving this condition is the existence of sound political control. Healthy socio-political control can be done by giving space to the mass media, political parties, and organizations civil society.

\section{METHOD}

The researcher used a qualitative descriptive method by using a literature review of a book study entitled "Metode Penelitian Kuantitatif, Kualitatif \& Penelitian Gabungan (Quantitative, Qualitative \& Joint Research Methods)" by Prof. Dr. A. Muri Yusuf, M.Pd. page 46 to 48 , a basic review used in research, then adjusted to the research topic discussed by the researcher. Qualitative methods are used to analyze data which is the source needed in the research process. The researchers analyzed and sorted out sources of information from the research materials according to the topics discussed. Through this method, the research results obtain results that can be proven.

The data collection technique used in doing this study was with used books by Lukman Hakim, with reference pages from 111 to 115, and the book by Deny JA with reference pages from 26 to 27. Journal articles from Google Scholar, several of them are Chronologia: Journal of History Education (2020), Journal of Social sciences and education, Journal of legal science, Social and Government, and trusted websites such as kompas.com. In collecting the data, researchers were organizing and selecting which one is essential for the conducted research.

The analysis techniques used in conducting literature review research are (5):

1. Prepare the equipment needed

2. Gather scientific sources following the topic to be discussed

3. Timing the analysis appropriately

4. Read and review scientific sources before conducting analysis

5. Analyze and conclude the sources that have been collected(21) 


\section{RESULTS}

In this study, fourteen journal articles were used from 2019 to 2020 and were strengthened by other sources in the form of two books from Playbook and the official and trusted website of four sites. The majority of journals are taken from Google Scholar with detailed articles containing the development of government systems from the past to the present, such as the parliamentary democratic government system, guided democracy, Pancasila democracy, reform democracy, and journals containing educational developments that have been implemented in Indonesia. In addition, there are also sources coming from the website from kompas.com and documents from the website containing information on the progress of human resources in Indonesia compared to other Southeast Asian countries and analysis of online learning.

\section{DISCUSSION}

\section{A. Indonesian Government History Overview}

History of nationalism, life, and state in Indonesia in the context of implementing the system of democratic governance, often divided into the steps of the old order, the new order, and order reforms(6). The power of President Soekarno's government (1945-1966) is referred to as the old order. This order was known as Guided Democracy, a Sukarno-style concept of democracy that was interpreted from the 1945 Constitution. In President Soeharto's rule, the New Order was called the New Order, which was carried out from 1966 to 1998, known as the legal, political policy of Pancasila Democracy with the principle of "implementing Pancasila purely and consistently." Then the reformation order was a period of government that began with the sign of the fall of the Suharto government in May 1988 (6).

The development of the democratic government of the Indonesian state based on time is divided into four periods.

1. The period of 1945-1959 (Parliamentary Democracy)

The period of Parliamentary Democracy took effect for a month after President Soekarno declared independence and began to be strengthened by the 1945 and 1950 Constitutions. However, this system was deemed unsuitable for Indonesia. The 1950 constitution determines the implementation of a parliamentary system with an executive body consisting of the president and his ministers responsible for politics. Since the political parties in each cabinet are based on one or even two major political parties and several minor political parties, resulting in poor relations between the parties, the related parties are also not afraid to withdraw their support at any time(7). 


\section{Period 1959-1965 (Guided Democracy)}

The dominance of the leader's role is the hallmark of a guided democratic system. In this period, political parties had limitations in carrying out their role, the influence of communists also developed in this era and the expansion of the role of ABRI as a sociopolitical(7). During this period, the government made many changes to the practice of democracy. The issuance of the Presidential Decree on July 5 was seen to find a way out of the political problems that occurred in the constituent assembly, which was a form of deviation from democratic practice(7).

Many deviations occurred in the practice of the democratic system, especially in the executive field. In the era of guided democracy, it was not a real democracy but a form of power that was led by itself or arbitrarily. The meaning of democracy in this era was not reflected or applied properly. Until the birth of the 30/September PKI Movement, the guided democracy of the Soekarno era was ended. (7)

3. The 1965-1988 period (Pancasila Democracy)

This period emerged after the 30/S PKI Movement, led by President Suharto. This period had a formal basis, namely Pancasila, the 1945 Constitution, and the MPRS stipulations. In this era, it aimed to restore and straighten the implementation of government based on Pancasila and the 1945 Constitution consistently and purely. To restore the government system from violating the 1945 Constitution during Guided Democracy, the Soeharto Government had taken corrective actions. In the period of Pancasila democracy, the practice of democracy reflected the values of Pancasila and the 1945 Constitution. Therefore, this period was called Pancasila democracy, in this democracy views the supreme power of the people over the state government as the core of this democratic system. However, Pancasila Democracy which was applied in the New Order period was only a language skill given by Suharto and his ideas had not yet arrived at the actual implementation(7). In the practice of administration and government, this regime did not provide space for its people to live a democratic life.

4. Reformation Period (1988-present)

During the Reformation period, the implementation of the democratic system began after the fall of President Suharto, who had served as president for approximately 32 years. Indonesian democracy in the reformation period became the beginning of laying a solid foundation in implementing democracy in the future. Although the character of the reform period is that it is a continuation of Pancasila democracy, the community is tasked with guarding democracy so that it can be applied in aspects of life. In this era, elections 
were more democratic; there was a change of leaders from the central government to the regions. Every citizen who is considered capable and fulfills the requirements can have a political position without distinction. The fundamental rights of the community are guaranteed, such as freedom of opinion (7).

After the reform period, political parties were able to grow freely, as a form of freedom in an organization, and finally, the political party system returned to multi-party (8). The change of the new order to reform marked the spirit of democracy and new hope in the aspect of freedom. The condition for achieving this condition is the existence of sound political control. Healthy socio-political control can be done by giving space to the mass media, political parties, and civil society organizations (1).

The implementation of comprehensive reforms is highly dependent on the condition of the community's strength and the reformation strength of the DPR and the government. According to Samuel Huntington (1993: 109-163) (Denny JA, 202: 30), three ways of change can be applied in Indonesia. First, the Transformation change was led by the reform elite within the government itself. An example of this type was applied by Brazil in the 1970s when President Giezel led it. Second, the Replacement change is led by an opposition figure who can unite the resistance movement. An example in this particular case was in the Philippines when Cory Aquino led it in 1986. Third, the Transplacement change was a change led by the cooperation of the opposition and reformers within the government itself. An example is South Africa under De Klerk (government) and Nelson Mandela (Opposition)(9).

The most secure and real for Indonesia to use is the change in the Transplacement model. This means that in this case, there must be cooperation between reformers in the government (DPR and ABRI) and the opposition (religious organizations, student groups, NGOs, professors, and other community groups). Apart from the cooperation between the reformers and the opposition, what is needed now is a little courage to take the risk of carrying out a complete reform. (9)

During the transition period after the fall of Suharto, the regime did not immediately change; there was a difficult transition period. Indonesia is in a volatile democracy. If the unstable democracy can continue to improve its quality will lead to a consolidated true democracy. On the other hand, if democracy is unstable, it can return to its original form, namely authoritarianism. We are familiar with the characteristics of authoritarianism, as reflected in the New Order's political system. In this regime, political sentiment does not 
allow for a change of power through general elections. Various mechanisms are arranged in such a way as to prevent the procedural transfer of power (9).

\section{B. The Role of Historical Education in the Modern Era}

The development of thinking and technology in the 20th century has resulted in significant life changes, much different from a previous life. The independence that has been achieved forms a new life between nations, with various competing understandings. Innovations influence rapid changes in political and economic life in technology and informatics. With the existence of information technology, people's connectivity between continents is easier and faster. In the 21 st century, life is full of changes compared to life in the previous century because more innovations in thinking and technology are growing rapidly (10).

For this reason, the preparation of the younger generation is very important to face the life of the 21 st century which is filled with many changes. Specifically, history education needs to develop three competencies related to change (Hamid, 2018b) (Hasan, 2019).

1. Competence in recognizing and understanding changes that have occurred in the past, present, to those that will occur in the lives of oneself, society, nation, and humans.

2. Competence to adapt to change and become actors who use technology instead of being controlled by technology.

3. Competence determines changes in a future life for oneself, the community, and the nation as technology users, not those controlled by technology. (10)

The current challenge is the emergence of the Covid-19 pandemic, which makes online learning activities or is said to be learning from home. Projo (2020) stated that teachers face two challenges when learning online during the Covid-19 pandemic. The first is the lack of teachers' readiness in dealing with changes in the learning system to be online. Second, teachers give too many assignments and too many learning materials, which causes students to object to online implementation. (11)

There are opportunities for teachers and history lecturers to utilize technology for the implementation of online learning today, and there is a virtual tour of cultural heritage that can be used to learn history when the online system was implemented (12). Several cultural heritage can be visited virtually through Google Arts and Culture, 1) Mount Merapi Museum, 2) Borobudur Temple, 3) Bungkarno's Tomb, 4) Brawijaya Museum, 5) Heroes Monument, 6) Mojokerto Puppet Gubug Museum, 7) Banteng Museum, 8) National Museum of Indonesia (12). In addition, the lack of preparation of lecturers or teachers in dealing with 
online learning, and students also complain about the many assignments or materials given by lecturers or teachers (13). With this, it can be seen that teachers and lecturers only focus on the cognitive domain, while the affective domain is also needed during this Covid-19 pandemic. In the affective domain, it is hoped that students will later have various kinds of characters related to national values because this is the affective domain that is important in learning history (Absor, et al, 2019)(14).

The industrial revolution 4.0 is an era where information technology develops rapidly and affects every human life. The industrial revolution 4.0 appeared marked by the development of the "Internet for everything" and penetrated various fields, one of which was education. Therefore, there are 2 efforts made, namely curriculum revitalization and appropriate information technology (15). Muhajir Effendy (the former Minister of Education) said The entry of revolution 4.0 into the world of education required curriculum improvements by increasing the competence of students, namely (Yusnaini, Y, 2019) critical thinking, creative and innovation, interpersonal skills and communication, teamwork and collaboration, and confident (16).

The internet and search engines (Google) quickly gave birth to the digital literacy movement. Many theories, concepts, practices, and types of knowledge via the internet can be searched easily and quickly. Along with the rapid access to data on the internet, the Indonesian government has launched three types of literacy starting in 2017: digital literacy in the face of the industrial revolution 4.0 (17). The concept of digital literacy is enhanced in the ability to analyze and use digital information obtained to avoid hoaxes and for proper use (17).

History lessons can be made easier to find historical sources or evidence related to learning. In this case, the teacher or lecturer must have the ability to explain historical events from various sources. As an event that has happened, history is considered a backward thing, even though history can be a lesson in the future. Therefore, researchers, teachers, and history buffs will usually ask how this event could have happened. New knowledge and experience are born and become lessons for life to come (18).

During the Covid-19 pandemic, learning that previously met face-to-face with teachers was now replaced with intermediaries through applications or only by meeting online. Although there have been many phenomena of declining national character formation lately, such as the ignorance of the first President of the Republic of Indonesia, it would be a shame if history just disappeared. Bung Karno once said, "Jas Merah" Which means never forget history. The role of the history teacher is very influential in providing teaching to 
students so that future generations will always know their nation's history. Moreover, the teacher conveys stories or historical events that have occurred and conveyed a Reformation about the meaning of historical events so that the benefits of history are appropriately conveyed (19).

\section{CONCLUSION}

History instructions may be made extra available to discover reasserts or historic proof associated with gaining knowledge of the outline above. In this case, the instructor or lecturer should have the cap potential to explain historic occasions from numerous reasserts. As an occasion that has happened, records are taken into consideration as a backward thing, even though records may be a lesson inside the future. Therefore, researchers, teachers, and records buffs will typically ask how this occasion may want to have happened. From that question, new understanding and reports are born and end up instructions for lifestyles to come.

Furthermore, in the Indonesian political system, healthy socio-political control can be exercised by giving space to the mass media, political parties, and civil society organizations. The most secure and accurate for Indonesia to use is the change in the Transplacement model. This means that in this case, there must be cooperation between reformers in the government (DPR and ABRI) and the opposition (religious organizations, student groups, NGOs, professors, and other community groups). Apart from the cooperation between the reformers and the opposition, what is needed now is a little courage to take the risk of carrying out a complete reform.

\section{REFERENCES}

1. Hakim L. Filsafat Ilmu dan Logika : Dialektika Perubahan Setyabudi MNP, editor. Klaten: Penerbit Lakeisha; 2020.

2.F IP, Nabilla2 C. Analisis sistem pemerintahan di indonesia pada demokrasi di era sby dan jokowi. Social and Government. 2020 September; Volume 1.

3. Wijaya jh, zulfikar a, permatasari ia. Implementasi sistem e-voting untuk meningkatkan kualitas demokrasi di indonesia. Jurnal pemerintahan dan kebijakan (jpk). 2019; volume i(1).

4. Pratama AM. Indeks Modal Manusia Indonesia Kalah Jauh dari Singapura dan Vietnam. [Online].; 2019 
[cited 2021 Mei 21. Available from: https://money.kompas.com/read/2019/08/14/142900226/indeksmodal-manusia-indonesia-kalah-jauh-dari-singapura-dan-vietnam.

5. Camelia f. Analisis landasan ilmu pengetahuan dan teknologi dalam pengembangan kurikulum. Sap (susunan artikel pendidikan). 2020 agustus ; vol. 5 no. 1.

6. Pakaya s, dali a. Demokrasi dan sistem kepartaian di indonesia. At-tanwir law review. 2021, februari; volume 1.

7. Purnamawati e. Perjalanan demokrasi di indonesia. Solusi. 2020 mei; volume 18.

8. Muhammad HA, Baidawi A. Rekayasa Desain Sistem Pemerintahan Presidensial di Indonesia yang Efektif. Jurnal Ilmu Sosial dan Pendidikan. 2020 Juli; Vol. 4.

9. Ja d. Jatuhnya soeharto dan transisi demokrasi indonesia: cerah budaya indonesia; 2021.

10. Hasan SH. Pendidikan sejarah untuk kehidupan abad ke 21. Historia: jurnal pendidik dan peneliti sejarah. 2019) april; vol. Ii.

11. Prodjo WA. Apa itu Belajar dari Rumah? Melihat Kembali Konsep Awal. [Online].; 2020 [cited 2021 Mei 22. Available from: https://edukasi.kompas.com/read/2020/04/14/163041771/apa-itu-belajar-dari-rumahmelihat-kembali-konsep-awal?Page=all.

12. Ramadhian N. Saatnya Virtual Traveling, 16 Museum Digital Indonesia yang Bisa "Dikunjungi". [Online].; 2020 [cited 2021 Mei 22. Available from:

https://travel.kompas.com/read/2020/03/17/220300227/saatnya-virtual-traveling-16-museum-digitalindonesia-yang-bisa-dikunjungi?Page=all.

13. Absor NF. Pembelajaran Sejarah Abad 21: Tantangan dan Peluang dalam. Chronologia: Journal of History Education (2020). 2020 Juli; Volume 2.

14. Absor NF, Umasih U, Kurniawati K. Pembelajaran Sejarah di SMK Era. Jurnal Teori Dan Praksis. 2019 Oktober; volume 4.

15. Nastit fe, 'abdu arn. Kesiapan pendidikan indonesia. Jurnal kajian. 2020 april; volume 5.

16. Yusnaini y, slamet s. Era revolusi industri 4.0: tantangan dan peluang dalam upaya meningkatkan literasi pendidikan. Prosiding seminar nasional pendidikan program pascasarjana universitas pgri. 2019 januari.

17. Risdianto e. Analisis Pendidikan Indonesia Di. [Online].; 2019 [cited 2021 Mei 22. Available from: https://www.academia.edu/38353914/Analisis Pendidikan_Indonesia di_Era Revolusi_Industri 4 _ 0 pdf.

18. Rahayu w. Pembelajaran sejarah untuk generasi z. Jurnal pendidikan sejarah indonesia. 2019 juni; vol. 2.

19. Susilo a, isbandiyah. Peran guru sejarah dalam pembentukan pendidikan karakter. Indonesian journal of social sceince education. 2019 juli; vol. 1. 
20. Nugraha s. Partisipasi masyarakat bagi pemerintah daerah. Jurnal ilmu hukum. 2020, juni; volume 6.

21. Prof. Dr. A. Muri Yusuf MP. Metode Penelitian Kuantitatif, Kualitatif \& Penelitian Gabungan. 1st ed. Fahmi I, Suwito, editors. Jakarta: Kencana; 2014. 